\title{
A Study of Knowledge Management and Organizational Learning under Environmental Education
}

\author{
Xue-Liang Pei ${ }^{1,2}$, Xiao-Li Man ${ }^{3^{*}}$, Ye-Zhuang Tian ${ }^{4}$ \\ ${ }^{1}$ College of Business Administration, Huaqiao University, Quanzhou, CHINA \\ 2 East Business Management Research Centre, Huaqiao University, Quanzhou, CHINA \\ ${ }^{3}$ School of Management, Harbin University of Commerce, Harbin, CHINA \\ ${ }^{4}$ School of economics and management, Harbin Institute of Technology, Harbin, CHINA
}

Received 14 December 2017 - Revised 18 April 2018 - Accepted 5 May 2018

\begin{abstract}
Under the globalized and fiercely competitive external environment, manufacturers have to enhance the organizational learning capability to cope with the challenge of Environmental Education. In addition to developing and cultivating the knowledge management capability, manufacturers have to co-develop, share, and spread relevant knowledge among different bodies in the external network. The theoretical relationship among manufacturers' knowledge management in global manufacturing network, knowledge management in supply chain network, and organizational learning capability is proposed in this study, and the moderation effect of Environmental Education is further discussed. Based on 2013 International Manufacturing Strategy Survey VI (IMSS VI) of 463 manufacturers in 22 countries and regions. The empirical research results are concluded as below. (1) Manufacturers' knowledge management in global manufacturing network and knowledge management in supply chain network present remarkably positive effects on the organizational learning capability. (2) Manufacturers' knowledge management in supply chain network shows mediation effects on the relationship between knowledge management in global manufacturing network and organizational learning capability. (3) Environmental Education reveals notable moderation effects on the relationship between manufacturers' knowledge management in supply chain network and organizational learning capability.
\end{abstract}

Keywords: environmental education, knowledge management, organizational learning capability, global manufacturing network, supply chain integration

\section{INTRODUCTION}

Globalized, dynamic, and fierce market competition are the features reflecting current manufacturers' external environment (Peng \& Meng, 2016). Under such environment, manufacturers have to reinforce the global competitiveness (Barrett, Balloun \& Weinstein, 2009; Ferdows, 1989; Huang, Zhang, \& Liu, 2013) which is realized through global marketing and global manufacturing (Rudberg \& West, 2008; Ruggero, Deflorin, \& Scherrer, 2016). International manufacturing initiated in 1980s and 1990s is regarded as an important composition for manufacturers acquiring competitive advantages (Ferdows, 1997). On the other hand, manufacturers have to enhance the organizational learning capability to cope with fiercely competitive and dynamic market environment (Stan \& Puranam, 2017). Globalized manufacturers' organizational learning capability, under Environmental Education, is therefore concerned in the academic circle.

Meanwhile, the knowledge-based economy has knowledge become the primary source to enhance organizational learning capability. Manufacturers have to develop and cultivate the knowledge management capability and co-develop, share, and spread relevant knowledge with different bodies in the external network (Cheng, Madsen, \& Liangsiri, 2010; Cheng, Chaudhuri, \& Farooq, 2016; Vereecke, Dierdonck, \& Meyer, 2006). Manufacturers, especially internationalized and globalized ones, have to pay attention to bodies in vertical

(C) 2018 by the authors; licensee Modestum Ltd., UK. This article is an open access article distributed under the terms and conditions of the Creative Commons Attribution License (http://creativecommons.org/licenses/by/4.0/). $\square$ peixueliangsx@163.com $\square$ marymxl@163.com (“Correspondence) $\square$ tianyezhuang@hit.edu.cn 


\section{Contribution of this paper to the literature}

- Environmental Education does not appear moderation effect on the relationship between knowledge management in global manufacturing network and knowledge management in supply chain network.

- This study presents certain practice value on the expansion of research on international operation management and supply chain integration as well as the knowledge management practice of Organizational Learning in multinational manufacturers.

industrial chain network, i.e. suppliers and customers, and other bodies in horizontal manufacturing network in the same globalized enterprises which are getting convergent (Brennan et al., 2015; Golini, Caniato, \& Kalchschmidt, 2017). The networks of such two types of manufacturers are the external networks of enterprises that, from the aspect of external network integration, manufacturers' knowledge management could be divided into knowledge management in supply chain network and knowledge management in global manufacturing network (Cheng et al., 2016). Accordingly, the relationship between manufacturers' knowledge management and organizational learning capability, under Environmental Education, is studied from the aspect of external network integration.

\section{LITERATURE REVIEW AND HYPOTHESIS}

Research on manufacturers, from the aspect of network (Barrett et al., 2009; Rudberg \& West, 2008), focuses on global manufacturing network composed of multiple manufacturers evolving from single production location to various manufacturing factories (Ferdows, 1997) and supply chain network composed of manufacturers and the supply chain partners (including suppliers and customers) (Rudberg et al., 2016; Zhao et al., 2011). From the aspect of external network integration, the effects of manufacturers' global manufacturing network and supply chain network on the organizations are discussed in this study.

Under the aspect of external network integration, Chakravarty, Ferdows, and Singhal (1997) classified manufacturers' embedded network into the international comparison of manufacturers' external network, mainly focusing on the features of countries or regions, in which manufacturers' external network is, or adaptation, and the design and management of goods, people, technology, and information in the studied network. Such research was further divided into network design and optimization with physical logistics or goods flow as the representatives and network management with the creation and transfer of intangible knowledge (containing technology, decision-making, plan, and information) as the representatives (Ferdows, 1997; Vereecke et al., 2006). Knowledge management in manufacturers' external network, i.e. the creation, sharing, absorption, and transfer of intangible technology, information, and decision-making, is focused in this study.

\section{Relationship Analysis of Manufacturers' Knowledge Management in Global Manufacturing Network and Organizational Learning Capability}

This study combines the viewpoints of Rudberg et al. (2016) and regards manufacturers' global manufacturing network as the process of collaboration, information sharing, and common decision-making between manufacturers and other manufacturers of the same multinational manufacturers to fulfill the target which cannot be realized by a single factory (Ruggero et al., 2016; Shi \& Gregory, 1998).

From the aspect of resource-based view, Manufacturers in multinational manufacturers could commonly create and use technology assets with other manufacturers and transfer and absorb knowledge through the manufacturing network to enhance the operation efficiency and benefit. It is the key to promote organizational learning capability (Dunning, 1993; Ruggero et al., 2016; Vereecke et al., 2006). Some research also studied organizational learning capability from different aspects (Alegre, 2008; Camps et al., 2015; Jerez-Gómez et al., 2005). For instance, Bartlett and Ghoshal (1989) considered that manufacturing network could create learning opportunities for manufacturers from the same manufacturing network to enhance the organizational learning capability. Chew, Bresnahan, and Clark (1990) indicated that innovation knowledge could be transferred from the internal manufacturer to other manufacturers in the manufacturing network to enhance the performance of the manufacturer and even the entire network. Ghoshal and Bartlett (2005) and Forsgren, Holm, and Johanson (2007) pointed out the importance of the direct exchange, especially knowledge flow, between a manufacturer and other manufacturers in the manufacturing network to the manufacturer's development potential and even learning capability. Accordingly, the following hypothesis is proposed in this study.

H1: Manufacturers' global manufacturing network knowledge management, in the same multinational manufacturers, presents significantly positive effects on organizational learning capability. 


\section{Relationship Analysis of Manufacturers' Knowledge Management in Supply Chain Network and Organizational Learning Capability}

From the aspect of external network integration, a manufacturer needs to coordinate and manage the knowledge of other manufacturers of the same multinational manufacturers as well as acquire, share, and consolidate strategic knowledge and information with external partners (i.e. supply chain partners, mainly suppliers and customers) (Cheng et al., 2016; Lim, Moon, Kim, \& Lee, 2017; Swink, Narasimhan, \& Wang, 2007).

Knowledge coordination and management among manufacturers' external supply chains are regarded as an important integration (Golini et al. 2017; Rudberg \& West, 2008). Researchers indicated that a manufacturer could more effectively plan and predict the product production and process design through the coordination and sharing of knowledge and information with key suppliers to enhance the organizational learning capability (Golini et al. 2017). Meanwhile, a manufacturer could more effectively provide market prediction and opportunity insight through tight coordination and sharing of knowledge and information with customers to better comprehend customers and establish tight links with customers to promote the operation performance and organizational learning capability (Golini et al. 2017; Swink et al., 2007; Wong, Boon-Itt, \& Wong, 2011). Comprehensively, a lot of studies received the research result of positive effects of manufacturers' external knowledge management in supply chain network on organizational learning capability.

Cheng et al. (2016) also indicated that the effects of manufacturers' external supply chain integration on operation performance and organizational learning capability could be applied to deal with manufacturers in multinational manufacturers (Flynn, Huo, \& Zhao, 2010; Lim et al., 2017; Wong et al., 2011). In this case, the following hypotheses are proposed in this study.

H2: Manufacturers' knowledge management in multinational manufacturers and external knowledge management in supply chain network show remarkably positive effects on organizational learning capability.

H2a: Manufacturers' knowledge management in multinational manufacturers and knowledge management in external supplier network reveal notably positive effects on organizational learning capability.

H2b: Manufacturers' knowledge management in multinational manufacturers and knowledge management in external customer network appear significantly positive effects on organizational learning capability.

\section{Relationship Analysis of Manufacturers' Knowledge Management in Global Manufacturing Network, Knowledge Management in Supply Chain Network, and Organizational Learning Capability}

A lot of researchers noticed that manufacturers in multinational manufacturers had to emphasize knowledge coordination and management in global manufacturing network as well as knowledge coordination and management of external suppliers and customers of multinational manufacturers; both global manufacturing network and supply chain network presented critical effects on the operation performance and organizational learning capability of manufacturers (Cheng et al., 2016; Golini et al. 2017; Meyer, Mudambi, \& Narula, 2011; Rudberg \& Olhager, 2003). Nevertheless, research on supply chain integration and manufacturing network was mainly done independently and ignored the co-influence of global manufacturing network and supply chain network (Cheng, Farooq, \& Johansen, 2015; Cheng et al., 2016; Golini et al. 2017).

As a matter of fact, when taking multinational manufacturers as the research object, a single manufacturer in multinational manufacturers had to consider the effects of global manufacturing network and supply chain network, which were manufacturers' external network (Cheng et al., 2016; Golini et al. 2017; Rudberg et al., 2016). From the aspect of manufacturers' knowledge management in multinational manufacturers, some research revealed that manufacturers with high-level control and low-level knowledge coordination and management in global manufacturing network would show lower level of knowledge coordination and management in supply chain network (Birkinshaw, Hood, \& Young, 2005; Gammelgaard et al., 2012). On the other hand, manufacturers with higher level of knowledge coordination and management would be more interested in higher level of knowledge coordination and management in supply chain network (Cheng et al., 2016). Meanwhile, in manufacturers' knowledge coordination and management process, the knowledge acquired from manufacturers' cooperation and technology improvement in the same global manufacturing network might be transferred to suppliers and customers to enhance the operation performance and organizational learning capability (Childerhouse \& Towill, 2011; Golini et al. 2017; Miltenburg, 2009). Besides, manufacturers' requirement for knowledge coordination and management in supply chain network is based on the knowledge coordination and management in global manufacturing network and other manufacturers in (Cheng et al., 2016). Accordingly, the following hypothesis is proposed in this study. 
H3: In the same multinational manufacturers, manufacturers' knowledge management in external supply chain network present remarkable mediation effects on manufacturers' knowledge management in global manufacturing network and organizational learning capability.

\section{Relationship Analysis of Environmental Education to Manufacturers' Knowledge Management in Global Manufacturing Network, Knowledge Management in Supply Chain Network, and Organizational Learning Capability}

From the effects of Environmental Education on manufacturers' knowledge management in manufacturing network and knowledge management in supply chain network, the dispersion of manufacturers in manufacturing network global would result in more difficult knowledge coordination and management among manufacturers (Rudberg \& West, 2008). When Environmental Education is high, manufacturers' high-level knowledge coordination and management in global manufacturing network could enhance the organizational learning capability through knowledge management in supply chain network, and the relationship between such two external networks would be enhanced to cope with Environmental Education. On the contrary, the relationship between manufacturers' knowledge coordination and management in global manufacturing network and knowledge management in supply chain network would reduce with changing environment when Environmental Education is low (Arora, Arora, \& Sivakumar, 2016; Ataseven \& Nair, 2017; Kopnina \& Cocis, 2017; Zhu, Krikke, \& Caniels, 2017; Hosseinnezhad, 2017). In this case, Environmental Education remarkably moderates the relationship between manufacturers' knowledge management in global manufacturing network and knowledge management in supply chain network.

The following hypothesis is therefore proposed in this study.

H4: Environmental Education notably and positively moderates the relationship between manufacturers' knowledge management in global manufacturing network and knowledge management in supply chain network.

There is research on the relationship among Environmental Education, knowledge management in supply chain network, and organizational learning capability. Organizational learning capability in this study is the learning result, but not the learning process, i.e. improvement of organizational performance, which essentially discusses the effects of Environmental Education on knowledge management in supply chain network and improvement of organizational performance (Alegre, 2008; Camps et al., 2015; Jerez-Gómez et al., 2005). Koufteros, Vonderembse, and Jayaram (2005) found out significantly positive relations between market/sales plan decision-making and corporate performance under high Environmental Education and no remarkably positive relation under low Environmental Education. In this case, Environmental Education notably and positively moderates the relationship between knowledge management in supply chain network and organizational learning capability. The following hypothesis is therefore proposed in this study.

H5: Environmental Education notably and positively moderates the relationship between manufacturers' knowledge management in supply chain network and organizational learning capability.

\section{Control Variable}

In the study on the effect of organizational learning capability, other variables, e.g. organization size (Cheng et al., 2016; Swink et al., 2007), might appear influence that organization size, as the control variable, is included in the theoretical model.

\section{RESEARCH METHODOLOGY}

\section{Theoretical Model}

The research hypotheses are proposed according to the theory analysis of the relationship among Environmental Education, knowledge management in global manufacturing network, knowledge management in supply chain network, and organizational learning capability of manufacturers in multinational manufacturers to form the theoretical model for this study, Figure 1. 


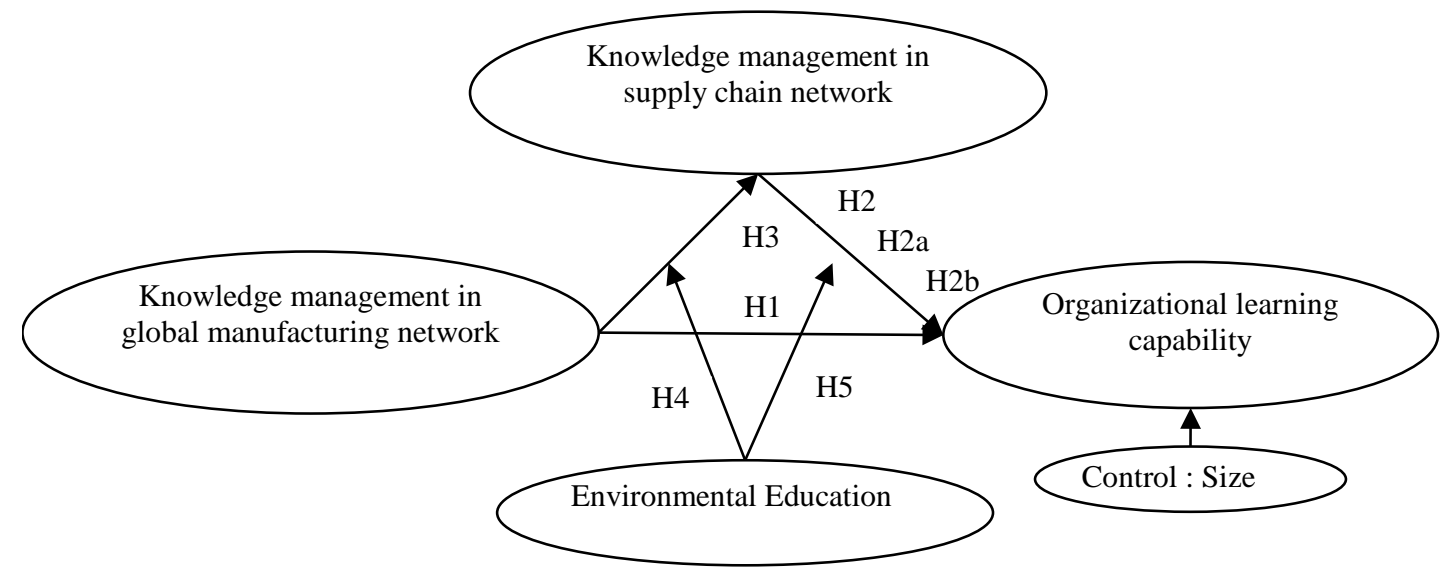

Figure 1. The relationships of the proposed hypotheses

\section{Sample and Data Survey}

The data used in this study are acquired from International Manufacturing Strategy Survey VI (the sixth version of International Manufacturing Strategy Survey, IMSS VI). The survey was done in June 2013-June 2014, about the development conditions of manufacturers three years before the end of 2012. The complete survey was announced in September, 2014. The surveyed manufacturers contained more than 50 employees and were classified in the industries in International Standard Industry Code 25-30 (ISIC 25-30).

The questionnaire is originally made in English. When it is used in other countries, researchers in the field have to translate it into the language in the country and different researchers translate it into English for the comparison. It aims to ensure the content consistency of the questionnaire in different countries.

Meanwhile, according to the research purpose, 463 manufacturers in multinational manufacturing network of 931 manufacturers from 22 countries, are selected, and the selected samples distribute in the surveyed 6 industries.

\section{Measurement of Variable}

When measuring the variables, the correspondent questions are extracted from IMSS VI. Each question is measured with Likert 5-point scale.

The measurement of the knowledge coordination and management of manufacturers in multinational manufacturers and other manufacturers is referred to the viewpoints of Colotla et al. (2003) and Cheng et al. (2015) that the knowledge coordination of information, decision-making, innovation, technology improvement, and network performance management system in past three years is measured.

The measurement of manufacturers' knowledge coordination and management in supply chain network is referred to Rudberg and West (2008) and Golini et al. (2017) that the knowledge coordination of information, decision-making, and cooperation methods of the surveyed manufacturers and the major suppliers and customers in past three years is measured.

The measurement of manufacturers' organizational learning capability in this study is the learning result, but not the learning process. Thus, they is referred to Wang and Satow (1994), Jerez-Gómez et al. (2005), and Lyu, Wu, $\mathrm{Fu}$, and $\mathrm{Xu}(2016)$ that the simple adaptation and the organizational learning capability, i.e. manufacturers with improved operation performance (including costs, quality, delivery, innovation, service, softness, and environmental production) compared to three years ago, is used for measuring organizational organizational learning capability. Besides, organizational learning capability is divided into efficiency organizational learning capability and cost organizational learning capability because of different improvement directions of costs and efficiency.

Referring to Davis (1993) and Chen et al. (2004), the changes of market scale, customer needs, and technology faced by manufacturers are used for measuring Environmental Education.

Meanwhile, organization size, as the control variable, is included in the model to ensure the contextual validity of the result. Referring to Peng et al. (2013), the logarithm of the number of employees is used for measuring organization size. 
Table 1. Regression coefficients

\begin{tabular}{|c|c|c|c|c|c|c|c|c|}
\hline \multirow{3}{*}{$\begin{array}{l}\text { Independent } \\
\text { variable }\end{array}$} & \multicolumn{6}{|c|}{ Dependent variable } & \multirow[b]{2}{*}{ Step3a } & \multirow[b]{2}{*}{ Step3b } \\
\hline & Step1a & Step1b & Step2a & Step2b & Step3a & Step3b & & \\
\hline & $\begin{array}{c}\text { Suppliers' } \\
\text { knowledge } \\
\text { management }\end{array}$ & $\begin{array}{c}\text { Customers' } \\
\text { knowledge } \\
\text { management }\end{array}$ & $\begin{array}{l}\text { efficiency } \\
\text { learning } \\
\text { capability }\end{array}$ & $\begin{array}{c}\text { cost } \\
\text { learning } \\
\text { capability }\end{array}$ & $\begin{array}{l}\text { efficiency } \\
\text { learning } \\
\text { capability }\end{array}$ & $\begin{array}{c}\text { cost } \\
\text { learning } \\
\text { capability }\end{array}$ & $\begin{array}{c}\text { efficiency } \\
\text { learning } \\
\text { capability }\end{array}$ & $\begin{array}{c}\text { cost } \\
\text { learning } \\
\text { capability }\end{array}$ \\
\hline \multicolumn{9}{|l|}{ Control variable } \\
\hline $\begin{array}{l}\text { Logarithm of } \\
\text { organisation size }\end{array}$ & $.0 .137^{\star *}$ & $0.114^{\star *}$ & -0.020 & 0.015 & -0.054 & -0.015 & -0.020 & -0.014 \\
\hline \multicolumn{9}{|l|}{$\begin{array}{l}\text { Independent } \\
\text { variable }\end{array}$} \\
\hline $\begin{array}{l}\text { knowledge } \\
\text { management in } \\
\text { global } \\
\text { manufacturing } \\
\text { network }\end{array}$ & $0.513^{* \star}$ & $0.537^{\star \star}$ & $0.349^{* *}$ & $0.206^{\star *}$ & $0.222^{\star \star}$ & 0.095 & $0.209^{\star *}$ & 0.070 \\
\hline $\begin{array}{l}\text { supplier } \\
\text { knowledge } \\
\text { management }\end{array}$ & & & & & $0.248^{\star \star}$ & $0.218^{\star \star}$ & & \\
\hline $\begin{array}{l}\text { customers } \\
\text { knowledge } \\
\text { management }\end{array}$ & & & & & & & $0.261^{\star \star}$ & $0.254^{\star *}$ \\
\hline
\end{tabular}

\section{Test of Reliability and Validity}

Cronbach's a is used for measuring the reliability of variables in this study. Applying SPSS19.0 to test the reliability, the results reveal the reliability of knowledge management in global manufacturing network 0.877 , the reliability of supplier knowledge management in supply chain network 0.858 , the reliability of customer knowledge management 0.852 , the reliability of Environmental Education 0.787 , and the reliability of organizational learning capability 0.906 . They all confirm to the basic reliability requirement.

Exploratory Factor Analysis is used for testing the validity of data. Common factors with the accumulated variance rate not lower than $40 \%$ and the factor load larger than 0.5 are extracted, revealing the achievement of basic validity requirement. The Exploratory Factor Analysis result, with SPSS19.0, shows the validity conforming to the basic requirement.

\section{RESULTS}

Based on the theoretical model and the questionnaire survey, Regression Analysis is used for testing the hypotheses. In the process, Stepwise Regression Analysis is applied to test the relationship among knowledge management in global manufacturing network, knowledge management in supply chain network, and organizational learning capability, where the mediation effect of knowledge management in supply chain network is tested by referring to Kenny, Kashy, and Bolger (1998). The specific results are shown in Table 1.

Table 1 presents the regression analysis results. Manufacturers' knowledge management in global manufacturing network shows significantly positive effects on cost learning capability and efficiency learning capability in organizational learning capability that H1 is proved. Meanwhile, manufacturers' knowledge management in supply chain network reveals remarkably positive effects on cost learning capability and efficiency learning capability in organizational learning capability that $\mathrm{H} 2$ is proved.

To test H3, both manufacturers' knowledge management in global manufacturing network and knowledge management in supply chain network are included in the regression equation. Table 3 lists the research results. Supplier knowledge management presents partial mediation effect on knowledge management in global manufacturing network and cost learning capability, supplier knowledge management shows full mediation effect on knowledge management in global manufacturing network and cost learning capability, customer knowledge management reveals partial mediation effect on knowledge management in global manufacturing network and cost learning capability, and customer knowledge management appears full mediation effect on knowledge management in global manufacturing network and cost learning capability. H3 is therefore proved. 
Table 2. Test of moderation effect of Environmental Education on the relationship between knowledge management in global manufacturing network and knowledge management in supply chain network

\begin{tabular}{|c|c|c|c|c|c|c|c|}
\hline \multirow{2}{*}{\multicolumn{2}{|c|}{ Step Variable }} & \multicolumn{3}{|c|}{$\begin{array}{c}\text { dependent variable: supplier } \\
\text { knowledge management }\end{array}$} & \multicolumn{3}{|c|}{$\begin{array}{c}\text { dependent variable: customers } \\
\text { knowledge management }\end{array}$} \\
\hline & & equation 1 & equation 2 & equation 3 & equation 1 & equation 2 & equation 3 \\
\hline \multirow{4}{*}{1} & control variable & & & & & & \\
\hline & organization size & $0.134^{\star \star}$ & $0.132^{\star \star}$ & $0.132^{\star \star}$ & $0.112^{\star \star}$ & $0.114^{\star \star}$ & $0.114^{\star \star}$ \\
\hline & argument & & & & & & \\
\hline & $\begin{array}{l}\text { knowledge management in global } \\
\text { manufacturing network }\end{array}$ & $0.520^{\star \star}$ & $0.523^{* *}$ & $0.523^{* *}$ & $0.546^{* *}$ & $0.543^{* *}$ & $0.544^{\star *}$ \\
\hline \multirow{2}{*}{2} & moderator & & & & & & \\
\hline & Environmental Education & & -0.022 & -0.032 & & 0.037 & 0.038 \\
\hline \multirow[t]{4}{*}{3} & $\begin{array}{l}\text { knowledge management in global } \\
\text { manufacturing network*Environmental } \\
\text { Education }\end{array}$ & & & -0.022 & & & -0.034 \\
\hline & $R^{2}$ & 0.30 & 0.30 & 0.30 & 0.324 & 0.325 & 0.326 \\
\hline & $\Delta R^{2}$ & 0.00 & 0.00 & 0.00 & 0.324 & 0.001 & 0.001 \\
\hline & Sig. of $R^{2}$ & 0.000 & 0.411 & 0.580 & 0.000 & 0.343 & 0.383 \\
\hline
\end{tabular}

Note: ${ }^{*} p<0.05,{ }^{* *} p<0.01$

Table 3. Test of moderation effect of Environmental Education on the relationship between knowledge management in supply chain network and organizational learning capability

\begin{tabular}{|c|c|c|c|c|c|c|c|}
\hline \multirow[t]{2}{*}{ Step } & \multirow[t]{2}{*}{ Variable } & \multicolumn{3}{|c|}{$\begin{array}{c}\text { dependent variable: efficiency } \\
\text { learning capability }\end{array}$} & \multicolumn{3}{|c|}{$\begin{array}{l}\text { dependent variable: cost learning } \\
\text { capability }\end{array}$} \\
\hline & & equation 1 & equation 2 & equation 3 & equation 1 & equation 2 & equation 3 \\
\hline \multirow{5}{*}{1} & control variable & & & & & & \\
\hline & organization size & -0.058 & -0.060 & -0.062 & -0.014 & -0.012 & -0.015 \\
\hline & argument & & & & & & \\
\hline & supplier knowledge management & $0.195^{* *}$ & $0.193^{* *}$ & $0.195^{* *}$ & $0.115^{*}$ & $0.118^{\star}$ & $0.119^{*}$ \\
\hline & customers knowledge management & $0.228^{\star *}$ & $0.232^{\star *}$ & $0.231^{\text {** }}$ & $0.199^{* *}$ & $0.195^{\star \star}$ & $0.193^{* *}$ \\
\hline \multirow{2}{*}{2} & moderator & & & & & & \\
\hline & Environmental Education & & -0.025 & -0.030 & & 0.029 & 0.019 \\
\hline \multirow{5}{*}{3} & $\begin{array}{l}\text { supplier knowledge } \\
\text { management*Environmental Education }\end{array}$ & & & -0.045 & & & -0.054 \\
\hline & $\begin{array}{l}\text { customers knowledge } \\
\text { management*Environmental Education }\end{array}$ & & & 0.058 & & & $0.113^{*}$ \\
\hline & $R^{2}$ & 0.148 & 0.149 & 0.050 & 0.078 & 0.077 & 0.085 \\
\hline & $\Delta R^{2}$ & 0.148 & 0.001 & 0.002 & 0.078 & 0.001 & 0.007 \\
\hline & Sig. of $R^{2}$ & 0.000 & 0.562 & 0.647 & 0.000 & 0.526 & 0.043 \\
\hline
\end{tabular}

To test $\mathrm{H} 4$ and H5, Environmental Education, as the moderator, is included in the regression equation to test the moderation effect. The steps are shown in Table $2 \& 3$.

Table 2 \& 3 reveal no moderation effect of Environmental Education on the relationship between knowledge management in global manufacturing network and knowledge management in supply chain network that $\mathrm{H} 4$ is refused. Meanwhile, Environmental Education does not show moderation effect on the relationship between knowledge management in supply chain network and efficiency learning capability, but notably positive moderation effect on the relationship between knowledge management in supply chain network and cost learning capability that $\mathrm{H} 5$ is partially proved.

\section{CONCLUSIONS}

Under Environmental Education, the theoretical analysis and empirical research are preceded for the relationship among manufacturers' knowledge management in global manufacturing network, knowledge management in supply chain network, and organizational learning capability. The research results are concluded as followings.

(1) Manufacturers' knowledge management in global manufacturing network presents significantly positive effects on cost learning capability and efficiency learning capability in organizational learning capability. It proves $\mathrm{H} 1$ and is consistent with previous research on the relationship between global manufacturing 
network and organizational performance (Cheng et al., 2015, 2016; Ferdows \& Thurnheer, 2011; Rudberg \& West, 2008). The research result explains that the knowledge coordination and management of manufacturers in multinational manufacturers and other manufacturers is getting important with the globalization development and directly determines the improvement of organizational learning capability and performance.

(2) Manufacturers' knowledge management in supply chain network reveals remarkably positive effects on cost learning capability and efficiency learning capability in organizational learning capability. It proves $\mathrm{H} 2$ and is consistent with the research on the relationship between supply chain integration and operation performance (Golini et al. 2017; Swink et al., 2007; Wong et al., 2011). The research result explains the important function of manufacturers' knowledge coordination and management in supply chain network to the organizational learning capability and operation performance.

(3) Manufacturers' knowledge management in supply chain network appears notable mediation effect on the relationship between knowledge management in global manufacturing network and organizational learning capability. Such a research result proves $\mathrm{H} 3$ and expands the research on the relationship between global manufacturing network and supply chain network recently concerned by researchers in international operation management (Cheng et al., 2015, 2016; Golini et al. 2017). Meanwhile, from the value chain theory of enterprises, manufacturers' knowledge management in global value chain is regarded as the auxiliary activity in value chain. The value realization requires the management of supply chain network, especially the management of customer network. For this reason, manufacturers have to further coordinate and manage knowledge in supply chain network, based on the knowledge coordination and management in global manufacturing network, to reinforce the organizational learning capability and promote the operation performance.

(4) Environmental Education does not appear moderation effect on the relationship between knowledge management in global manufacturing network and knowledge management in supply chain network. Since multinational manufacturers are the research objects in this study, and manufacturers in multinational manufacturers are restricted and controlled by multinational manufacturers that they are not sensitive to Environmental Education. Such an analysis is consistent with the research on the effects of autonomy of manufacturers in multinational manufacturers on the operation performance (Golini et al. 2017).

(5) Environmental Education does not reveal moderation effect on the relationship between knowledge management in supply chain network and efficiency learning capability, but shows significantly positive moderation effect on the relationship between knowledge management in supply chain network and cost learning capability. Such a research result partially proves $\mathrm{H} 5$ and is partially consistent with research on the moderation effect of Environmental Education on the relationship between supply chain integration and operation performance. It also explains the effects of Environmental Education on supply chain integration, which requires further study (Ataseven \& Nair, 2017).

This study presents certain practice value on the expansion of research on international operation management and supply chain integration as well as the knowledge management practice of manufacturers in multinational manufacturers. Regarding the knowledge management of manufacturers in multinational manufacturers, the research results indicated that (1) manufacturers should emphasize the knowledge management in global manufacturing network and knowledge management in supply chain network, which present remarkably positive effects on organizational learning capability, (2) manufacturers in multinational manufacturers should stress on knowledge management in global manufacturing network and then emphasize knowledge management in supply chain network, rather than invest in large amount of resources at the same time, (3) manufacturers in multinational manufacturers should focus more on customer knowledge management in knowledge management in supply chain network when Environmental Education is large to enhance the organizational learning capability under high Environmental Education.

This study presents the following restrictions. (1) When stressing on the network in which a manufacturer is, the internal network is not taken into account. (2) This study merely focuses on manufacturers' organizational learning capability, but not the financial performance and strategic performance, which require further discussion in future research.

\section{ACKNOWLEDGEMENTS}

The author would like to acknowledge the MOE (Ministry of Education in China) Project of Humanities and Social Sciences (Project No. 17YJC630110), the National Science Foundation of China (No. 71372089) and Huaqiao University's Research Foundation for Talented Scholars (No. 13Y00025) for financial support and 2014 International Manufacturing Strategy Survey (IMSS VI) for data support in conducting this research. 


\section{REFERENCES}

Alegre, J. (2008). Assessing the impact of organizational learning capability on product innovation performance: an empirical test. Technovation, 28(6), 315-326. https:/ / doi.org/10.1016/j.technovation.2007.09.003

Arora, A., Arora, A. S., \& Sivakumar, K. (2016). Relationships among supply chain strategies, organizational performance, and technological and market turbulences. International Journal of Logistics Management, 27(1), 206-232. https:/ / doi.org/10.1108/IJLM-09-2013-0103

Ataseven, C., \& Nair, A. (2017). Assessment of supply chain integration and performance relationships: a metaanalytic investigation of the literature. International Journal of Production Economics, 185(9), 252-265. https://doi.org/10.1016/j.ijpe.2017.01.007

Barrett, H., Balloun, J., \& Weinstein, A. (2009). How variation in management perceptions affects organizational performance. Quality and Quantity, 43(3), 451-461. https:/ / doi.org/10.1007/s11135-007-9122-2

Bartlett, C. A., \& Ghoshal, S. (1989). Managing Across Borders: The Transnational Solution. Hutchinson Business Books, Boston, MA.

Birkinshaw, J., Hood, N., \& Young, S. (2005). Subsidiary entrepreneurship, internal and external competitive forces, and subsidiary performance. International Business Review, 14(2), 227-248. https:// doi.org/10.1016/j.ibusrev.2004.04.010

Brennan, L., Ferdows, K., Godsell, J., Golini, R., Keegan, R., Kinkel, S., Srai, J. S., \& Taylor, M. (2015). Manufacturing in the world: where next? International Journal of Operations \& Production Management, 35(9), 1253-1274. https://doi.org/10.1108/IJOPM-03-2015-0135

Camps, J., Oltra, V., Aldás-Manzano, J., Buenaventura-Vera, G., \& Torres-Carballo, F. (2015). Individual performance in turbulent environments: the role of organizational learning capability and employee flexibility. Human Resource Management, 55(3), 363-383. https:/ / doi.org/10.1002/hrm.21741

Chakravarty, A., Ferdows, K., \& Singhal, K. (1997). Managing international operations versus internationalizing operations management. Production and Operations Management, 6(2), 100-101.

Chen, I. J., Paulraj, A., \& Lado, A. A. (2004). Strategic purchasing, supply management, and firm performance. Journal of Operations Management, 22(5), 505-523. https:/ / doi.org/10.1016/j.jom.2004.06.002

Cheng, Y., Chaudhuri, A., \& Farooq, S. (2016). Interplant coordination, supply chain integration, and operational performance of a plant in a manufacturing network: a mediation analysis. Supply Chain Management, 21(5), 550-568. https:// doi.org/10.1108/SCM-10-2015-0391

Cheng, Y., Farooq, S., \& Johansen, J. (2015). International manufacturing network: past, present and future. International Journal of Operations \& Production Management, 35(3), 392-429. https:/ / doi.org/10.1108/IJOPM03-2013-0146

Cheng, Y., Madsen, E. S., \& Liangsiri, J. (2010). Transferring knowledge in the relocation of manufacturing units. Strategic Outsourcing: An International Journal, 3(1), 5-19. https:/ / doi.org/10.1108/17538291011023043

Chew, W. B., Bresnahan, T. F., \& Clark, K. B. (1990). Measurement, coordination and learning in a multiplant network. In R. S. Kaplan (Ed.), Measures for Manufacturing Excellence, Harvard Business School Press, Boston, MA, pp. 129-162.

Childerhouse, P., \& Towill, D.R. (2011). Arcs of supply chain integration. International Journal of Production Research, 49(24), 7441-7468. https:/ / doi.org/10.1080/00207543.2010.524259

Davis, T. (1993). Effective supply chain management. Mit Sloan Management Review, 34(4), 35-46.

Dunning, J. H. (1993). Multinational Enterprises and the Global Economy. Addison-Wesley, Reading, MA.

Ferdows, K. (1989). Mapping international factory networks. In K. Ferdows (Ed.), Managing International Manufacturing, Elsevier Science, New York, NY.

Ferdows, K. (1997). Made in the world: the global spread of production. Production \& Operations Management, 6(2), 102-109. https:/ / doi.org/10.1111/j.1937-5956.1997.tb00418.x

Ferdows, K., \& Thurnheer, F. (2011). Building factory fitness. International Journal of Operations E Production Management, 31(3), 916-934. https:/ / doi.org/10.1108/01443571111165820

Flynn, B. B., Huo, B., \& Zhao, X. (2010). The impact of supply chain integration on performance: a contingency and configuration approach. Journal of Operations Management, 28(1), 58-71. https://doi.org/10.1016/j.jom.2009.06.001

Forsgren, M., Holm, U., \& Johanson, J. (2007). Managing the Embedded Multinational: A Business Network View. Cheltenham: Edward Elgar Publishing. 
Gammelgaard, J., McDonald, F., Stephan, A., Tüselmann, H., \& Dörrenbächer, C. (2012). The impact of increases in subsidiary autonomy and network relationships on performance. International Business Review, 21(6), 11581172. https:/ / doi.org/10.1016/j.ibusrev.2012.01.001

Ghoshal, S., \& Bartlett, C. A. (2005). The multinational corporation as an inter-organizational network. In S. Ghoshal \& D. E. Westney (Eds), Organization Theory and the Multinational Corporation, Palgrave MacMillan, Houndmills.

Golini, R., Caniato, F., \& Kalchschmidt, M. (2017). Supply chain integration within global manufacturing networks: a contingency flow-based view. Journal of Manufacturing Technology Management, 28(3), 34-352. https://doi.org/10.1108/JMTM-11-2015-0100

Hosseinnezhad, F. (2017). A Study of the New Environmental Paradigm Scale in the Context of Iran. European Journal of Sustainable Development Research, 1(2), 14. https:/ / doi.org/10.20897/ ejosdr.201714

Huang, G. Q., Zhang, A., \& Liu, X. (2013). A supply chain configuration model for reassessing global manufacturing in china. Journal of Manufacturing Technology Management, 24(5), 669-687. https:/ / doi.org/10.1108/17410381311327963

Jerez-Gómez, P., Céspedes-Lorente, J., \& Valle-Cabrera, R. (2005). Organizational learning capability: a proposal of measurement. Journal of Business Research, 58(6), 715-725. https://doi.org/10.1016/j.jbusres.2003.11.002

Kenny, D. A., Kashy, D. A., \& Bolger, N. (1998). Data analysis in social psychology. In D. Gilbert, S. T. Fiske \& G. Lindzey (Eds.), Handbook of Social Psychology (4th ed., Vol. 1), New York: McGraw-Hill.

Kopnina, H., \& Cocis, A. (2017). Testing Ecocentric and Anthropocentric Attitudes toward the Sustainable Development (EAATSD) Scale with Bachelor Students. Journal of Cultural Analysis and Social Change, 2(1), 2. https://doi.org/10.20897/ejsa.201702

Koufteros, X., Vonderembse, M., \& Jayaram, J. (2005). Internal and external integration for product development: the contingency effects of uncertainty, equivocality, and platform strategy. Decision Sciences, 36(1), 97-133. https:/ / doi.org/10.1111/j.1540-5915.2005.00067.x

Lim, D., Moon, Y., Kim, K., \& Lee, H. (2017). A Methodology for Searching and Allocating Enterprises in the Supply Chain by Using the Business Information Database and Trademark Rights Database. Science, Technology and Society, 22(3), 524-538. https:/ / doi.org/10.1177/0971721817724317

Lyu, H., Wu, L., Fu, Z., \& Xu, S. (2016). The effect of the interplay between business model design and organizational complexity on organizational adaptation. Chinese Journal of Management, 13(3), 374-384

Meyer, K. E., Mudambi, R., \& Narula, R. (2011). Multinational enterprises and local contexts: the opportunities and challenges of multiple embeddedness. Journal of Management Studies, 48(2), 235-252.

Miltenburg, J. (2009). Setting manufacturing strategy for a company's international manufacturing network. International Journal of Production Research, 47(22), 6179-6203. https:/ / doi.org/10.1080/00207540802126629

Peng, C., \& Meng, Y. (2016). Empirical study of manufacturing enterprise collaboration network: formation and characteristics. Robotics and Computer-Integrated Manufacturing, 42(5), 9-62. https:/ / doi.org/10.1016/j.rcim.2016.05.005

Peng, D. X., Verghese, A., Shah, R., \& Schroeder, R. G. (2013). The relationships between external integration and plant improvement and innovation capabilities: the moderation effect of product clockspeed. Journal of Supply Chain Management, 49(3), 3-24. https:/ / doi.org/10.1111/j.1745-493x.2012.03286.x

Rudberg, M., \& Olhager, J. (2003). Manufacturing networks and supply chains: an operations strategy perspective. Omega, 31(1), 29-39. https:/ / doi.org/10.1016/S0305-0483(02)00063-4

Rudberg, M., \& West, M. B. (2008). Global operations strategy: coordinating manufacturing networks. Omega, 36(1), 91-106. https:/ / doi.org/10.1016/j.omega.2005.10.008

Ruggero, G., Deflorin, P., \& Scherrer, M. (2016). Exploiting the potential of manufacturing network embeddedness: an om perspective. International Journal of Operations \& Production Management, 36(12), 1741-1768. https://doi.org/10.1108/IJOPM-11-2014-0559

Shi, Y., \& Gregory, M. (1998). International manufacturing networks-to develop global competitive capabilities. Journal of Operations Management, 16(2), 195-214. https:/ / doi.org/10.1016/S0272-6963(97)00038-7

Stan, M., \& Puranam, P. (2017). Organizational adaptation to interdependence shifts: the role of integrator structures. Strategic Management Journal, 38(5): 1041-1061. https:/ / doi.org/10.1002/smj.2546

Swink, M., Narasimhan, R., \& Wang, C. (2007). Managing beyond the factory walls: effects of four types of strategic integration on manufacturing plant performance. Journal of Operations Management, 25(1), 148-164. https:// doi.org/10.1016/j.jom.2006.02.006 
Vereecke, A., Dierdonck, R. V., \& Meyer, A. D. (2006). A typology of plants in global manufacturing networks. Management Science, 52(11), 1737-1750. https:/ / doi.org/10.1287/mnsc.1060.0582

Wang, Z., \& Satow, T. (1994). Leadership styles and organizational effectiveness in Chinese-Japanese joint ventures. Journal of Managerial Psychology, 9(4), 31-36. https:/ / doi.org/10.1108/02683949410063645

Wong, C. Y., Boon-Itt, S., \& Wong, C. W. (2011). The contingency effects of Environmental Education on the relationship between supply chain integration and operational performance. Journal of Operations Management, 29(6), 604-615. https:/ / doi.org/10.1016/j.jom.2011.01.003

Zhao, X., Huo, B., Selen, W., \& Yeung, J. H. Y. (2011). The impact of internal integration and relationship commitment on external integration. Journal of Operations Management, 29(1), 17-32. https://doi.org/10.1016/j.jom.2010.04.004

Zhu, Q., Krikke, H., \& Caniels, M. (2017). Supply chain integration: value creation through managing interorganizational learning. International Journal of Operations \& Production Management, 28(2), 488-507.

\section{http://www.ejmste.com}

